\title{
Religion and food
}

\author{
EDITORIAL
}

\begin{abstract}
Thec he current $26^{\text {th }}$ volume of Scripta Instituti Donneriani Aboensis is based on a symposium arranged by the Donner Institute in June 2014, under the title: 'Religion and Food'. All the articles published in this volume were initially presented as papers or keynote addresses at this conference and have, through a double-blind peer-review process, been selected for this volume.
\end{abstract}

The relationship between food and religion is a lived activity formed by the dynamics of both tradition and adaption. Religious commitments to food are influenced by several different factors, ranging from personal spirituality and experiences to social patterns of belonging as well as ethical, political and doctrinal convictions related to food and eating. Today, this topic is receiving increasing scholarly attention and has become a relevant focus to a broad spectrum of researchers working with different religious traditions and contemporary spiritualities. The conference aimed at addressing the questions of why and how persons of various religious and spiritual liaisons seem to engage in food and eating with a growing zeal today from a variety of different theoretical and methodological angles. Papers were presented on the interconnectedness of religion and food and themes such as: folkways/foodways and vernacular practices; tradition, memory, and nostalgia; boundaries, identity, and control; symbolism, authenticity, and fluidity; consumption and abstention; ethics and environmentalism; the global, local, and glocal. Teaching methods, fieldwork and methodology also received much attention.

As conference organisers, we were especially grateful for the lively and nuanced discussions that marked the event, as well as the excellent academic calibre of the contributions, some of which we are proud to publish in this issue. We were also pleased to see that another important tradition of the Donner Symposia was honoured: the speakers of the conference included researchers from all stages of the academic path: students, doctoral students, senior researchers, professors and emeriti. More than half a century separated the most junior and the most senior participants: a great span of experiences and perspectives. The conference papers also covered the whole span of human history, from antiquity and all the way up until today, from several different theoretical 
and methodological points of view, exploring several different religious traditions. We hope that this discussion will continue through the personal contacts and networks created during the conference and through the publication of selected conference papers in this volume.

The volume opens with two theoretically-oriented papers. Benjamin E. Zeller analyses emerging 'quasi-religious foodways' in the USA and show how they offer individuals a way to engage in discourses of community, personal and group identity, and boundary-marking within the logics of the market. Graham Harvey introduces a theoretically innovative way of understanding the relationship between religion and eating by giving pre-eminence to the latter as a key to understanding the entire field of Religious Studies. Two papers with a theological focus follow. Michel Desjardin applies modern, cross-cultural, anthropologically-grounded food data to the historical Jesus in order to facilitate a more realistic and human image of him. Panu Pihkala, in his turn, deals with the research field of ecotheology and especially themes of food, eating, and Christian theology, which have gained ground during recent years.

Four articles dealing with historical perspectives on religion and food follow. Natalia Moragas and Elena Mazzetto analyse offerings of maize in Central Mexico from the Classic period to early colonial times on the basis of archaeological material. Gioia Filocamo discusses sin and rebellion through food and music in the lives of women in Early Modern Italy. The following article, written by Andrea Gutierrez, deals with the same time period but moves the geographical focus to India and the many modes of religious betel leaf consumption of that time. India is the context also of Bindu Malieckal's article, which demonstrates how food in terms of spices was the foundation of power for ethno-religious groups on the continent during the period of the spice trade in the sixteenth and seventeenth centuries.

The following six articles all have a more contemporary perspective and rely on ethnographical research conducted by the authors. Ulrica Söderlind explores the foodways of Jews, Christians and Muslims in the Georgian capital of Tbilisi while the laws guarding religious freedom in Italy and their application in relation to religious dietary restrictions is the topic of Miriam Abu Salem's article. Katarina Plank describes the 'foodscape' of the Thai Buddhist diaspora in Sweden, dealing especially with the strategies developed by the communities to facilitate supporting their temples. Moving geographically over the Atlantic to the Americas, David Walsh deals with the implications of climate change for the traditional foodways of the subarctic indigenous Dene people. Joanna Zamorska, for her part, analyses the role of food and alcohol in Mexican patronal feasts while Patricia Rodrigues de Souza presents the role of votive foods in African Brazilian Candomblé. 
The final section of four articles all deal with Jewish perspectives on the conference theme. Paulette Kershenovich Schuster presents the foodways of Jews with a Mexican background living in Israel and how spiritual and cultural ties to the previous home country is preserved in food. A radical Sabbatical approach to Jewish food reform in the United States, combining the religious tradition of the Shmita Year with ecological concerns, is analysed by Adrienne Krone. A similar theme is dealt with by Aldea Mulhern, who discusses what 'eating Jewishly' means among participants of a Jewish environmental programme in Toronto, Canada. Finally, Ben Kasstan presents his ethnographic study of ageing Shoah survivors in the UK and how food for them awakens reflections and emotions tied to their childhood trauma.

The volume ends with an article by the winner of the Donner Prize for Outstanding Research into Religion 2014, Elina Hankela. The prize, which Hankela received during the conference, was awarded for her ethnographic study of an inner-city Methodist church in Johannesburg, South Africa, and the tensions between traditional hospitality (ubuntu) and exclusionary xenophobia arising as a result of massive immigration of refugees from neighbouring Zimbabwe.

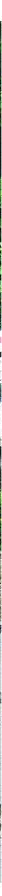

Participants in the Donner Symposium 'Religion and Food' in June, 2014. Photograph by Björn Dahla. 
This is the first volume of Scripta to be published solely as an electronic publication. During the past year, we have developed the entire series, inaugurated in 1967 , into an open access e-publication, digitalising previous issues so that all volumes are now available online through the open access publishing platform OJS. In its new digital version, Scripta provides immediate open access to its content on the principle that making research freely available to the public supports a greater global exchange of knowledge. Open access publication is rapidly increasing in significance and is heavily promoted by most important research supporting agencies. By going online, thus, we strive to meet the requirements of the academic world of today. Nevertheless, for those who still wish for a printed book to keep in hand, print-on-demand arrangements can be made by contacting the Donner Institute.

Simultaneously, we have also strengthened the academic standard of Scripta by implementing a more formal peer-review process for the articles published in the series, which now undergo a double-blind peer-review evaluation before being accepted for publication. In order to facilitate this assessment and to secure the academic standard of our publication also in the future, we have appointed an editorial board consisting of prominent scholars of religion from around the world, representing a wide variety of subfields, theoretical and methodological approaches and cultural contexts within the study of religion.

This is also the first volume where Ruth Illman has hade the privilege to act as editor. Luckily, she has had the opportunity to work together with her experienced colleague Björn Dahla, who has been involved in the work around Scripta for decades already! We hope that the current issue of Scripta will become an important resource for research and teaching in the field of food and religion and wish you inspiring and illuminating reading.

Turku/Åbo, 6 April 2015 RUTH ILLMAN and BJÖRN DAHLA 